\title{
Symbolic and social boundaries of the integration of Russian immigrants in Czechia
}

\section{Ekaterina Ignatyeva*}

Charles University, Faculty of Science, Department of Social Geography and Regional Development, Centre for Urban and Regional Research, Czechia

* Corresponding author: kateignatyeva@gmail.com

\begin{abstract}
This article focuses on the integration process of Russian immigrants into Czech society. The integration of immigrants into Czech society is a key topic in the public debate as well as a political issue. Ukrainians, Slovaks, Vietnamese, and Russians are the most numerous groups within the half-million migrant population. Czechia is therefore predominantly attractive to non-EU immigrants. Representing highly educated and financially well-secured migrants who come as entire families, the Russians are distinct from other Eastern European immigrants. However, various factors hinder their integration. The article discusses the factors that shape symbolic and social boundaries in this integration process: (1) the development of Czech-Russian relationships that have been influenced by dramatic past events, (2) the representation of Russians in Czech media, (3) their specific socio-economic status, and (4) Czech immigration and integration policies. Negative experience, socio-economic inequalities, strict implementation of immigration policies towards third-country immigrants, and an unfavourable media discourse affect the attitudes of the majority toward the Russians and limit meaningful encounters.
\end{abstract}

\section{KEYWORDS}

symbolic and social boundaries; immigration and integration policies; media discourse; Russian immigrants; Czechia

Received: 24 April 2019

Accepted: 20 May 2020

Published online: 3 July 2020

Ignatyeva, E. (2020): Symbolic and social boundaries of the integration of Russian immigrants in Czechia. AUC Geographica 55(2), 137-148

https://doi.org/10.14712/23361980.2020.10

(C) 2020 The Author. This is an open-access article distributed under the terms of the Creative Commons Attribution License (http://creativecommons.org/licenses/by/4.0). 


\section{Introduction}

With the rapid growth of immigrants in Czechia, the issue of their integration becomes important at the institutional level through the implementation of immigration policy, as well as at the social level due to its impact on public opinion in society. During the integration process, immigrants try to find their own way in different areas of life within a host country. Meanwhile, members of the majority may not hinder, but rather, they may aid and support societal newcomers. Hence, integration is considered a two-way as well as a reciprocal process (Bosswick, Heckmann 2006), where both immigrants and the majority may participate. On both sides, participation is necessarily conditioned by mutual interaction that mostly manifests in coexistence at the local level, where encounters between foreigners and members of the majority society come about most often.

Prague increasingly attracts foreigners and belongs to regions with their highest concentration (Czech Statistical Office 2019). Immigrants transform the capital of Czechia into a cosmopolitan city. The most numerous groups of up to half a million migrants in whole Czechia include Ukrainians (23\%), Slovaks $(21 \%)$, Vietnamese $(11 \%)$, and Russians $(7 \%)^{1}$. In this article, I focus on Russian immigrants living in Czechia. Russians are particularly distinct from other foreigners from Eastern Europe, especially in terms of their composition. They represent a group of highly educated, economically well-resourced immigrants of working age who migrate as whole families (Drbohlav et al. 2010; Drbohlav, Janská 2004).

According to the intergroup contact hypothesis (Pettigrew 1998; Allport 1954), in countries with larger numbers of immigrants, there are better opportunities for encountering and social interaction that improve the majority attitudes towards immigrants through prejudice reduction. Even though today the number of immigrants in Czechia is 14 times higher than in 1989 and is continuously growing, members of the Czech majority society, particularly of the older generation, still have negative attitudes towards foreigners. In contrast, the younger generation comes into contact with foreigners more so; and most of them have foreigners as work colleagues or schoolmates - a common circumstance today. Some of the reasons for this impact on the attitudes of the older majority generation are (1) a lack of experience with international migration in Czechia, and thus, locals have not become used to the presence of 'others' yet, and (2) relatively recent dramatic events in Czech history, such as the Soviet military intervention and occupation of Czechoslovakia, that are remembered by elders to this day. The results of the 2017 Eurobarometer survey show that, in a comparison of EU

1 According to data from the Directorate of the Alien Police Service from 31 December 2018. countries, Czechia is the country with the most negative attitudes towards immigrants. Concerning the situation inside Czechia, the assessment of majority attitudes indicates that 64 percent of Czechs consider immigrants a problem (Public Opinion Research Centre 2017). Interestingly, this indicator has never dropped below fifty percent over the past ten years, since 2003. With regard to Russians, the Czech majority manifests more antipathy than sympathy towards them, and, moreover, the attitude of Czechs towards the Russians has grown worse in recent years (Public Opinion Research Centre 2017).

Pettigrew (1998) argues that not only social contacts, but also cultural, economic, political factors, media discourse, and dramatic social events influence majority attitudes towards immigrants. Similarly, several different factors that contribute to making boundaries influence Czech attitudes towards Russians, and therefore, slow down or block integration processes. In this article, I discuss factors (historical, discursive, socio-economic, and institutional) that have a significant impact on the integration process of Russian immigrants into Czech society.

The aim of the article is to explore the context of the integration process through the concept of symbolic and social boundaries (Lamont, Molnár 2002) with an emphasis on (1) the historical development of Czech-Russian relationships, which has undergone both positive and negative events in the past; (2) representation of Russians in Czech media discourse; (3) the socio-economic status of Russians that distinguish them from 'others'; and (4) modes of Czech immigration and integration policies that disadvantage the legal status of Russians as third-country immigrants over EU immigrants. This article significantly contributes to understanding how symbolic and social boundaries between Russian immigrants and the Czech majority are created and influence everyday negotiation by limiting encounters that hinder the integration of immigrants. The results will be useful predominantly for integration policymakers in the setting, development, and improvement of integration activities for foreigners.

First, the article discusses the theoretical framework, which is built around the concept of symbolic and social boundaries (Lamont, Molnár 2002). After this, I briefly introduce the research methods. From the methodological point of view, in regard to research on the development of Czech-Russian relationships, I study the available literature on this subject. Next, an analysis of the Czech press serves as a methodical approach to investigating the discourse of media coverage concerning Russian immigrants. A description of the specific socio-economic status of Russian immigrants follows. Finally, there is an attempt to explain the institutional status of Russians through an analysis of the development of Czech immigration and integration policies. The article's main findings are in the following section, and in conclusion, there 
is a summary of the research results and an explanation of how the discussed factors impact the attitudes of the majority towards Russians and, consequently, how they hinder the integration process of Russian immigrants into Czech society.

\section{Theoretical and methodological frameworks}

\subsection{Symbolic and social boundaries}

In this article, I use the concept of symbolic and social boundaries by Lamont and Molnár (2002) to describe barriers in the process of Russian integration into Czech society as well as to evaluate the incorporation process through the historically developed attitudes of the majority, media discourse, the specific socio-economic status of Russian immigrants, and the implementation of immigration policies. By categorising objects, people, practices, time, and space, people draw symbolic boundaries that help individuals and social groups identify each other and, at the same time, to determine their belonging within a particular group during the negotiation of everyday life (Lamont, Molnár 2002). Thus, symbolic boundaries contribute to the emergence and maintenance of a dichotomy of 'us' and 'them' or the in-group and the out-group.

Symbolic boundaries, however, could transform into social boundaries, which are broadly accepted in society (Lamont, Molnár 2002). Unequal access to resources, their distribution, and different social opportunities shape social boundaries in a society, which are 'objectified forms of social differences' (Lamont, Molnár 2002: 168). Social boundaries are often institutionalised (Bail 2008; Heizmann 2016) and policy-oriented (Neumann, Moy 2018), determining who in a society can or cannot access resources (material and non-material), define social opportunities (Lamont, Molnár 2002), and consolidate social inequalities. Even though symbolic and social boundaries are closely connected and 'should be viewed equally as real' (Lamont, Molnár 2002: 169), symbolic boundaries are a 'necessary but insufficient condition for the existence of social boundaries' (Lamont, Molnár 2002: 169).

Symbolic boundaries are formed discursively based on our subjective perceptions and are also influenced by representations from the outside. Today, the depiction of immigrants in media discourse plays an active role in shaping and reinforcing symbolic boundaries. Media might represent immigrants in different ways positive, negative, or neutral. However, negative portrayals mostly contribute to the drawing of symbolic boundaries. Frames, where immigrants are linked with crime or terrorism, represent them as a threat to the receiving society, creating negative attitudes in the majority towards newcomers (Sohoni, Sohoni 2014;
Caviedes 2015; Estrada et al. 2016) which limit mutual encounters and influence immigrant incorporation.

Boundaries may become exaggerated by frames based on stereotyping or which emphasise the 'otherness' of the immigrant (Estrada et al. 2016). In particular, defining who 'we' are and who 'they' are may lead to distinguishing society as 'us' and 'them'. As a result, there is no favourable environment where fruitful social interactions can arise. Importantly, the immigrant voice is generally almost always missing in media coverage as well. Immigrants belong to the 'others' as well as poor, handicapped people, sexual and ethnic minorities, who exclude from the 'normal values of Western culture' (Spivak 1999). Simultaneously immigrants belong to the discourse powerless salient social group, that less quoted or that have less to say (van Dijk 1988). As van Dijk (1988) asserts, people who are neglected in the press are people who are neglected in social life. According to van Dijk (1988: 140) 'there is not much difference between the free press of the Western countries or the more controlled press in most communist and many Third World countries'. Thus, by ignoring the opinion of immigrants, the media deprives them of justification, and, on the other hand, provides readers a biased view of immigrants.

How immigrants are described or labelled in media coverage creates public opinion and policy outcomes (Sohoni, Sohoni 2014; Bleich et al. 2015; Estrada et al. 2016); in other words, media discourse may have an impact on immigration policies. In particular, representations of restrictive immigration legislation in media contribute to the maintenance of symbolic boundaries, especially when readers rely principally on the media discourse in place of the original legislative resources or actual law texts (Estrada et al. 2016). Nevertheless, I will discuss immigration legislation as a separate dimension of boundary-making below.

According to Estrada et al. (2016), the government continues to be a key player in drawing boundaries among groups of immigrants and natives through immigration law-making. Social boundaries are manifested by restrictive immigration policies that 'draw a sharper line between "us" and "them", highlighting or brightening boundaries' (Heizmann 2016: 1793). Immigration legislation provides immigrants with unequal rights in comparison to those that citizens enjoy. Immigrants may have different rights even within one country. For instance, in the European context, there is a distinction between immigrants from the EU and non-EU countries and third countries (Heizmann, Böhnke 2018). This distinction between immigrants and natives results in the creation of social boundaries. However, for third-country immigrants living in the EU, there is an extra layer of social boundaries that define them as both as foreigners and as non-EU immigrants. Contrarily, integration policies endeavour to reduce inequalities and achieve equilibrium between immigrants and non-immigrants. 
Here it is necessary to mention the importance of the time aspect, respectively the time of arrival and duration time that influence boundary-making. It is a difference in the time when migrant arrived in a new country, precisely it depends on how many migrants this country has? How more restrictive immigration policy towards newcomers? How many experiences locals have with living in a multicultural society and which attitudes they have towards foreigners? etc. Another important aspect is the duration time of the foreigner's stay. First, as time goes on, it comes about a mutual habit and adaptation, on both part, of foreigners and locals. Second, and more important is, with increasing a duration time in a new country, the migrant acquires more and more rights in society, and at the same time, has to overcome less and less boundaries.

This article examines symbolic boundaries found in the Czech media coverage of Russian immigrants. The perception of historical experiences with Russians as well as the current conditions of Czech-Russian relations influence the Czech media's representation of Russians. Moreover, Czechia, as a post-socialist country, is in transition and is still dealing with its heritage. Večerník (2002) points to the social transformations of Czech society, especially human mentality and behaviour patterns that are not completed yet (Sýkora, Bouzarovski 2012). Klvaňová (2018) concerns herself with the shaping of symbolic boundaries between Russian speaking immigrants and Czechs through an examination of collective memory - in particular, the cultural trauma caused by the Soviet military intervention and occupation of Czechoslovakia in 1968. She found that Czech society perceives immigrants from the former Soviet Union as 'colonizers', devolves responsibility for past acts of occupational violence to current immigrants, marks them as 'others', and keeps them at a distance due to the former dominance of the Soviet regime (Klvaňová 2018). Thus, cultural trauma in Czech society contributes to the stigmatisation of newcomers through past negative experiences and draws symbolic boundaries (Klvaňová 2018). Russia's current geopolitical behaviour (for example, its violation of international law in the annexation of another state's territory) also significantly influences the majority attitudes towards its citizens.

Social boundaries are primarily represented by an immigrant's socio-economic status. Most Russians come to Czechia with a high-level socio-economic status and try to keep or enhance it upon arrival. This points to the differences between Russian immigrants and other Russian-speaking foreigners from the East. On the other hand, Russians belong to third-country immigrants; thus, unlike immigrants from EU countries, they have much more difficult entry conditions, access to the labour market, and limited possibilities to use other state benefits (for instance, access to public health insurance, the right to vote, etc.). On that account, it is necessary to examine the implementation of Czech immigration and integration policies that shape social boundaries by distinguishing among immigrants from EU and non-EU countries and reinforces them at the institutional level. In the next section, I briefly discuss the research methods.

\subsection{Research design}

The article offers the results of three-part research. Firstly, a historical development overview of Czech-Russian relationships provides a summary of previous detailed academic research and studies built upon the memories of immigrant descendants, analyses of documents from historical archives, as well as a discussion of the current situation.

Secondly, the representation findings were discovered through an analysis of Russian immigrant coverage in the online version of Czech newspapers. The media analysis focused on four of the most read Czech national daily newspapers, such as Lidové noviny, Deník, Blesk, and Reflex, whose articles have been under observation throughout an eight-year period (2011-2018). The important reason for choosing these newspapers was the simple logical claim that the most read sources have a wider target audience which could be affected by reading its content.

Newspapers articles were searched using the keywords 'Russian' and 'Russians' on newspapers' websites which archives were available online. The keywords 'migrant' and 'immigrant' were not using for the purpose to reduce or eliminate the useless incidence of found articles that deal with immigrants in general. The selection of articles had to concern information about Russian immigrants as a main requirement. Each found article was read and its information value detected. Articles that did not directly deal with Russian immigrants living in Czechia were excluded. For instance, articles about tourism, sport, culture, and international politics. If the article contained relevant information, it was included in the database of articles in the form of a simple Excel spreadsheet. Articles were categorised by topic in order to ascertain what is written and spoken of in the Czech press in relation to Russian immigrants. The total number of found articles revealed whether the Russians are popular in the Czech media discourse or not. Subsequently, the following characteristics were identified for each article: geographic level (national, regional, local), type of narrative with the numbers of each type, and the possible participation of Russians.

Finally, the article offers (1) a discussion of the socio-economic status of Russian immigrants based on 2011 census data from Czech Statistical Office with emphasis on three features - income, education, and occupation - and (2) an assessment of their legal status via an evaluation of Czech immigration and integration policies, which was based on an overview of their general development from 1990 and any relevant changes. The analysis focuses specifically 
on immigrants from the third countries (including Russians) and their institutional position in society as a result of implemented immigration policies. To compare with EU immigrants, I discuss the limits and disadvantages of Czech immigration policies towards immigrants from non-EU countries that contribute to the creation of social boundaries in the integration process.

Nevertheless, there are some limitations of the study. The first part which deals with the historical development overview is limited by the lack of numbers of academic studies about Czech-Russian relationships. The Russians are not much explored immigrants' groups in Czechia for instance in contrast to Ukrainians or Vietnamese minorities. The analysis of media discourse about Russian immigrants based on the research of newspapers only - it is the second limitation of this research. It may be better to include the other media sources - TV, radio, and social networks on the Internet (e.g. Facebook, Twitter, Instagram, etc.). On the other hand, this would lead to the overshoot an extent of the article and would make it possible to create another independent article, hence the media discourse of this article is represented only by analysis of the press.

\section{Results}

\subsection{Heritage of the past: Development of Czech-Russian relationships}

Different historical events influence the current attitudes of Czechs towards Russian immigrants. Since the establishment of the Czechoslovak and Czech Republics, there have been three waves of Russian immigration. Sládek (2010) gave names to these waves according to the periods in which they took place: the First Republic wave (1918-1948), the socialist wave (1948-1989), and the post-socialist wave (1989-present). The individual waves differ from each other by volume and structure of immigrants, their motivation to move, and the attitudes of the Czech receiving society. Moreover, the migration history of Russians is characterised itself by alternating voluntary and involuntary migration periods.

Czech-Russian relationships arose in 1918, during the first Czechoslovak Republic, when Russian students, professors, scientists, and wealthier intelligentsia (Kopřivová 2001) were forced to flee from Tsarist Russia for political reasons (Sládek 2010) after the Bolshevik coup. Later, they were joined by Russian soldiers who did not want to return after the First World War, and therefore, stayed in Czechoslovakia. The largest concentration of Russian students and professors was in the capital of Czechoslovakia where most universities were located. Hence the reason 1920s Prague was nicknamed the 'Russian Oxford' (Sládek 2010). The newly established Czechoslovak state organised an unprecedented humanitarian action for Russians (the so-called 'Russian Action') that set up and secured not only the basic needs of the immigrants but also provided temporary asylum and the opportunity to study and work. The responsive Czechoslovak policy emphasised the cultural enrichment of Europe due to the presence of Russian refugees who carried with them the traditional Russian culture. The relationships between Czechs and Russians were mostly friendly at the beginning when all these actions appeared as a temporary situation. However, when Russians realised the way back was definitely closed, they had to accustom themselves to their new home while the Czechs had to come to terms with the permanent presence of new citizens and learn to live together. At this point, Russians started to build their own community, establishing societies, organisations, and institutions, some of which still function today (the Slavic Library in Prague, for instance). Sládek (1999) notes a disadvantage in the existence of these societies: the hermetic closeness of the Russians to the host society represented a major barrier to the process of their integration. Keeping their own Russian culture and traditions without an effort to assimilate to that of Czechs led to the shaping of symbolic boundaries by Russians themselves towards the receiving society.

Top among positive Czech-Russian relationships was a victory in World War II, and especially the liberation of Czechoslovakia by the Soviet Army; Czech people appreciated and were grateful towards Russian as well as Soviet soldiers. After the end of the Second World War in 1945, there was a certain euphoria in Czech-Russian relations. The significant influence of the Soviet Union helped the Communist Party gain political power in Czechoslovakia and establish a communist totality in 1948. Although according to Večerník (2002) the communist regime was not successful and could not enter deep inside into the Czech society, it significantly influenced the behaviour of the Czech population, and these negative experiences are still passed on from generation to generation. During socialism, Czechs and Russians were connected by a lot of common things, for instance, economic and cultural relations (Sládek 2010). Eventually, previous open and fruitful mutual everyday interaction and collaboration have changed into pragmatic economic cooperation (Kratochvíl et al. 2006), and subsequently, it has moved towards the negative influence of Soviet power. The subordination and the increasing dependence on the Soviet Union led to the gradual destruction and backwardness of the Czechoslovak economy, which once was one of the most advanced in post-war Europe.

Unfortunately, in 1968, the Prague Spring was followed by the tragic Soviet occupation of Warsaw Pact troops, which ruled Czechoslovakia under orders from Moscow from that point on. Gratitude to the Russians for the liberation of Czechoslovakia in the 
Second World War was replaced by hatred towards any that had Russian roots due to the invasion. The negative experiences of the communist totality period form the foundation of the symbolic boundaries towards Russians and everything of Russian genesis. According to Klvaňová (2018), this collective trauma of communism in the majority society tends to reflect these events into the present and to devolve responsibility onto contemporary Russian and/or Russian-speaking immigrants.

After the events of 1989 took place, a third Russian migration wave began which continues to this day (Sládek 2010). At present, negative attitudes persist within Czech-Russian relations. And there are reasons for that. First, today's Russian immigrants inherit a 'collective guilt' for the 1968 occupation. A second reason reflects the typical xenophobic attitudes towards foreigners in general within Czech society. This negative reaction triggers a connection between Russians and the mafia, espionage, and perception of Russians as agents of Putin or the Kremlin.

Klvaňová (2018) also points to the potential threat of contemporary Russian imperialism, which is intensely perceived and monitored in Central and Eastern Europe. The Russian occupation of Crimea in 2014 and the subsequent war in the Donbas region evokes Czech memories of the 1968 invasion when every Czechoslovak was considered a victim and at the same time, every Russian had been perceived as a perpetrator (Klvaňová 2018). As a result of the deep-seeded post-communist collective trauma, contemporary Russia's geopolitical behaviour in the international arena is largely reflected by negative attitudes of the Czech majority towards Russian immigrants due to an equation of Russians with Russia. In August, Czech people annually remember the tragic events of 1968 - the 50th anniversary of the Soviet invasion of Czechoslovakia passed in 2018, stirring a great response in Czech public discourse. In the following section, the issues of the portrayal of Russians in Czech media will be discussed in more detail. Notwithstanding, it seems the more time passes, the more the events of 1968 have been made into a representative reminder of the post-communist trauma, thus sustaining the symbolic boundaries which are then reinforced and transferred onto the next generation.

The first and last waves of migration have much in common. Today, Russian students, intellectuals, and wealthy entrepreneurs choose Czechia as a migration destination, similarly to the first Czechoslovak Republic period. This tradition, however, today contains a significant critical point, where positive experiences from the past have been influenced by the negative events of the communism period. The communist regime and the Soviet occupation of Czechoslovakia have left a significant trail in the history of the Czechoslovak nation, which is still one of the primary causes behind the existence of symbolic boundaries in the process of negotiation between Czechs and Russians.
The influence of these negative past experiences on the representations of Russians in the Czech media will be discussed in the following section.

\subsection{Media coverage of Russian immigrants in the Czech press}

The media discourse analysis found 68 articles: 30 in Lidové noviny, 19 in Deník, 11 in Blesk, and 8 in Reflex. Considering this fact, we can claim that Russian immigrants are not the dominant object of Czech newspaper coverage. In terms of geographical scale (Fig. 1), $37 \%$ of the articles reported on Russians in the Czech national context. The regional level was represented in $56 \%$ of the articles; most of them dealt with Russian immigrants in Prague and Karlovy Vary, which is explained by the significant concentration of Russians in these two cities. Written about less frequently were Russians in other Czech cities, such as Brno, Hradec Králové, and Kunovice. In terms of the local level, only $7 \%$ of articles in the case of Prague focused on Russian immigrants living in the districts of Bubeneč, Nové Butovice, Zličín, Stodůlky, Letňany, and Vršovice. In a comparison between national and local levels, the same findings were discovered by Lawlor (2015), claiming that media discourse on immigrants is generally much more nationalised and mostly neglects the local context. However, in my analysis, the regional level emerged and was represented more often $(56 \%)$ than others.

The next finding in the discourse analyses concerns the participation of Russians in the media debate. The question is how often Russians are given the opportunity and space to express themselves in the Czech press? The media discourse analysis found only $16 \%$ of all articles include the opinions of Russian entrepreneurs, students, and journalists living in Czechia. Most of these articles are informative narratives, where Russians descript why Czechia is attractive to them. For instance, the high achiever Russian entrepreneur presents:

Czechia is attractive to the Russians because there is a close mentality ... Western European societies are very much based on tradition and are not influenced by communism. New traditions and relationships are now being built in Eastern Europe. Here, Russian integrates into society faster. In Western Europe, no matter how much money Russian has, he will always be a foreigner there. (Lidové noviny, 23.12.2018)

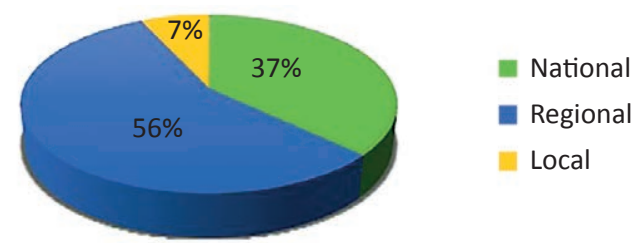

Fig. 1 Percentage of all articles by geographical levels. 
Media which offers the majority an immigrant's perspective directly has significant value in the creation and improvement of an individual's perception as well as public opinion about immigrants in general. Thus, an immigrant voice in media discourse can be used as a tool in the elimination of symbolic and/or social boundaries as well as in the prevention of their formation.

Found articles about Russians covered various narratives (Tab. 1), the most often discussed is their cohesion with the majority (21\%), entrepreneurship (16\%), activity on the real estate market (15\%), and criminality (15\%). Articles dealing with everyday negotiations between Russians with Czechs never provided information about conflicts or tensions, but rather they represented non-conflictual social interactions. Nonetheless, it is remarkable that articles concerning the everyday life of Russians in Czechia several times (29\%) made mention of the 1968 occupation. For instance, a resident from Carlsbad narrates about cohabitation Russians with locals, and about sometimes provocative behaviour from the Russian side:

The Russians still claim that Carlsbad is beautiful and that they are very well here. And gradually the local people from Carlsbad are getting used to them. Nevertheless, the Russians can dial locals almost reliably. For example, when they (Russians) indulge in fireworks on August 21st or when the Russians defeat the Czechs in hockey. The locals here do not forgive that. (Deník, 10.12.2011)

This demonstrates that media discourse maintains and reinforces symbolic boundaries which were initially created by negative past experiences. In articles about the housing or real estate market, Russians were usually described as owners of expensive luxury apartments - mostly in Karlovy Vary but Prague as well. This title of the article is a very good example that captures the nature of fondness for luxury property: 'Russians love Czechia. Castles are cheaper here' (Lidové noviny, 15.11.2011) Czech media discourse largely accuses Russian immigrants of raising property prices in such a way that others cannot afford them. Less attention was paid to topics dealing with the presence of Russians in Czechia generally and which related to outdated stereotypes from time to time $(12 \%)$.

Only $6 \%$ of found articles connected the Russians with espionage. This happened thanks to information within reports of the Security Information Service of Czechia (BIS), which mostly have a political context and are built on fears of Russia's geopolitical behaviour in the international arena (for more information about the securitisation of European media discourse see, for example, Caviedes 2015). 8\% of the articles dealt with the Russian presidential elections, or rather they portrayed the participation and election preferences of Russians living abroad. Bleich et al.
(2015: 861-862) noted that 'media outlets, especially print media in Europe, are often associated with particular political viewpoints'. As a result, an equation takes place between Russian immigrants living in Czechia and the political force in their motherland. These representations of Russians as spies create a particular perception within the majority society, which is accompanied by feelings of suspicion and mistrust towards the whole Russian immigrant population. This is yet another example of how boundaries can be created in the negotiation between the majority and immigrants. It is also worth mentioning that almost no attention was paid to the themes such as the Russian financial crisis (3\%), debts (1\%), church restitution (1\%), discrimination (1\%), and emigration from Russia (1\%).

Tab. 1 Percentage of all articles about Russian immigrants by narrative type.

\begin{tabular}{|l|c|}
\hline Narrative & \% of articles \\
\hline Cohesion with the majority, everyday life ${ }^{1}$ & 21 \\
\hline Entrepreneurship & 16 \\
\hline Real estate market activity & 15 \\
\hline Criminality & 15 \\
\hline Stereotypes & 12 \\
\hline Participation and election preferences & 8 \\
\hline of Russians abroad & 6 \\
\hline Espionage & 3 \\
\hline Russian financial crisis & 1 \\
\hline Debts & 1 \\
\hline Church restitution & 1 \\
\hline Discrimination & 1 \\
\hline Emigration & 8 \\
\hline
\end{tabular}

Source: own research

$129 \%$ of these narrative type articles mentioned the 1968 occupation.

Another interesting finding is that Czech print collectivises Russians when covering other Russian-speaking immigrants from former Soviet Union countries. Therefore, the narratives in these articles lead to a misrepresentation of reality, shaping media bias towards Russians. Only three articles of this sort were discovered in the research, but it is noteworthy that two of them deal with criminality. For instance, the title in Blesk newspaper introduces the crime as committed by Russians: "Two Russians raided a money truck: They neutralized the drivers with tear gas', but the content of the article tells us that they were not actual Russians and instead were possibly Russian-speaking foreigners or even people who speak a language similar to Russian: 'According to witnesses, one of them was nervously and loudly telephoning in Russian or similar language' (Blesk, 22.6.2015).

The question is how many people read only titles with this distorted reality, which therefore create a negative public perception of Russians and shape the majority attitudes towards them? Bleich et al. (2015) 
note that articles about immigrant individuals with a criminal or economic threat context can lead to representation of the whole group of immigrants as deeply problematic for society.

\subsection{Socio-economic status of Russian immigrants in Czechia}

A significant factor in the shaping of social boundaries is the socio-economic status (SES) of immigrants, which can be seen as a source of various inequalities. Russian immigrants living in Czechia are perceived by some scholars (e.g. Drbohlav et al. 2010; Janičko 2010) as an elite group of immigrants. They differ from the immigrants of other former Soviet countries in the following ways. First of all, there is a high level of education among Russians. Most of them (43\%) carry a university degree, which exceeds the Czech national average by more than three times (Czech Statistical Office 2011). However, it should be added that foreigners from Western Europe and the United States also come with a high education level. Russians also care about the education of their children and pay close attention to it. Believing in the European education system, which in their opinion is better and cheaper than Russian, they send their children to study abroad. This is confirmed by an increase of share of Russian students attending Czech universities from $4.9 \%$ in 2007 to $12.9 \%$ in 2019 (Czech Statistical Office 2019). Russians are confident that a high level of education provides better opportunities in obtaining well-paying jobs and general well-being.

The next specific feature that characterises Russians in Czechia is their high economic activity and type of occupation. Most of them run a business or do a highly-skilled job in a position that corresponds to their education level. As 2011 census data shows, $16.2 \%$ of Russians are frequently employed in wholesale or retail; $13.1 \%$ in the real estate sector; almost $9 \%$ of Russians carry out qualified, scientific, and technical activities; $8 \%$ are in manufacturing, 7.5\% in information and communication technologies; and $6.4 \%$ carry out administrative and support activities. This differs among Russians; for instance, Ukrainians, who are mostly employed in Czechia as construction workers or in manufactories, do lower-skilled jobs in comparison to the jobs they performed in their home country (Drbohlav, Janská 2004). Furthermore, it is typical of Russians to create an immigrant economy, which focuses on their compatriots or other Russian-speaking foreigners, allowing them to remain relatively independent and, at the same time, limiting their interaction with the Czech majority. In this case, Russians initiate the shaping of social boundaries themselves through the creation of their own small world with strong inner ties that help them to separate and close off from others, including Czechs.

Several studies show that Russian immigrants in Czechia are distinguished by their incomes not just from other foreigners but also from the Czech majority. For instance, a survey provided by Schebelle et al. (2015) found that Russians had the highest monthly income and lowest debt in comparison to Ukrainian and Vietnamese immigrants in Czechia. Vavrečková and Dobiášová (2015) discovered that in 2013 the average and median gross monthly salary of Russians in Czechia exceeded the average and median gross monthly salary of domestic inhabitants.

The specific features of Russian socio-economic status discussed above rank them among the most self-sufficient immigrants in Czechia, distinguishing them from others, including the Czech majority. This socio-economic division of 'us' and 'them' leads to a deepening of inequalities in society and, therefore, to the creation of social boundaries to which Russians contribute themselves.

\subsection{Czech immigration policies}

The history of Czech immigration policy is thirty years old. Some scholars (e.g. Barša, Baršová 2005; Drbohlav et al. 2010; Kušniráková, Čižinský 2011) distinguish five historical periods during which liberal and restrictive approaches cyclically alternated.

The first period took place between 1990 and 1996 when Czechia did not regulate or limit entry to its territory. This 'liberal tolerance' (Barša, Baršová 2005: 222) approach towards all foreigners in Czech immigration policy enabled free entry to the country but, as Drbohlav et al. (2009: 46) note, 'without a legal way for permanent residence or naturalization, except for marriage with a Czech citizen'.

Between 1996 and 1999, due to the deterioration of the socio-economic situation in Czechia as well as increasing numbers of illegal foreign workers, Czech immigration policy turned to a restrictive approach through a tightening of the rules. At the same time, Czechia became an EU candidate country and therefore sought to adapt its entry requirements accordingly. As a result, an amendment to Act No. 326/1999 Coll., on the Residence of Foreign Nationals in the Czech Republic, came into force, which complicated the lives of immigrants via the implementation of a visa requirement before entering Czechia (Drbohlav et al. 2009; Kušniráková, Čižinský 2011). Applications for a permanent residence permit were permissible after ten years of continuous stay in Czechia and only for the purpose of family reunification, employment/entrepreneurship, and humanitarian cases. In essence, this was the first step in creating institutionalised (Bail 2008; Heizmann2016) and politicised (Neumann, Moy 2018) social boundaries towards newcomers through the regulation of their entrance and residence.

The third period - 2000 to 2004 according to Barša and Baršová (2005) or 2006 in keeping with Kušniráková and Čižinský (2011) - was marked by a partial liberalisation. In 2004, Czechia joined the EU 
and the most important change in the Czech immigration policy came into force: a division of all immigrants into foreigners from EU and non-EU countries. Free entry, movement, and access to the Czech labour market was given to EU citizens and their family members - essential benefits distinct from immigrants coming from non-EU countries. It was the first significant change to bring disadvantages leading to institutionally rooted social boundaries, especially towards third-country immigrants (include Russians).

The next period, from 2005 to 2007 (Barša, Baršová 2005) or 2008 (Kušniráková, Čižinský 2011), was called a neoliberal immigration policy. A consequence of economic growth, Czechia was faced with a labour shortage, and the solution to this problem was the implementation of a green card as a way to attract a cheap labour force quickly (Drbohlav et al. 2010). The green card project existed from 2007 to 2009. As Drbohlav et al. (2010) note, Russians as well as foreigners from Vietnam, Moldavia, and Mongolia could not apply for a green card. Given the high socio-economic status of Russians, it was likely that they would not have been interested in this type of visa, which primarily targeted those doing low-skilled and poorly paid jobs. Despite this fact, this deprival of the opportunity to apply was the next brick in the wall of disadvantages and the drawing of social boundaries towards immigrants from Russia. In the middle of this period, in 2006, the length of a continuous stay in Czechia was shortened from ten to five years (Drbohlav et al. 2009).

The latest period of Czech immigration policy discussed in academic literature started in 2008 and continues to this day. Kušniráková and Čižinský (2011) call this time a neo-restrictive period during which entry and stay requirements have been tightened and entrance to Czechia for some nationals, such as Mongolians, Moldavians, Thais, Ukrainians, and Vietnamese, has been temporarily cancelled.

In 2011, the next amendment brought new, stricter application requirements. Every applicant must now provide proof of secure accommodation, health insurance, and funds for their stay in the country. Moreover, personal attendance when applying, as well as an interview with a police officer, makes the whole process longer and more apprehensive than before. Finally, the newly implemented permit card with biometric data increases expenditures for immigrants.

So as to attract a high-skilled labour force to Czechia, a blue card was later implemented and, in 2014, an employee card for all types of labour (including low-skilled) replaced the previous green card. According to the Ministry of Interior, there are two modes of the employee card: (1) dual, which contains residence and employment permits, and (2) non-dual, which offers a residence permit only - for foreigners with free access to the Czech labour market who (a) have obtained secondary, tertiary, tertiary professional, or university education in Czechia; (b) wish to be employed as a pedagogical/academic worker at a Czech university; or (c) have been posted to Czechia for the provision of services by his or her foreign employer based in some other EU state.

Two years later, in 2016, the next amendment to the Alien Act was implemented. Two types of permit residence newly came into existence: (1) a shortterm visa for seasonal workers and (2) a long-term residence permit for investment purposes. However, there were also restrictive changes. For instance, a further restrictive step was taken in terms of acquiring a permanent residence permit by children in cases of family reunification when those eligible were underage children. Such an unhappy implementation of immigration policy leads to the division of family members and seriously impacts Russians, who often move with the whole family. Therefore, one of the most common migration strategies for financially-secure Russians is to send their child to be educated in Czechia first and then move to them.

In 2018, a recent amendment of the Alien Act brought some liberal changes related to students and scientists who, after finishing their studies, may remain in Czechia for nine months for the purpose of seeking employment or practising entrepreneurship - finally Czechia has considered the human capital of foreign nationals into which it invests considerable funds (a foreigner may study in Czech language free of charge and after graduation they now have free access to the national labour market). Today, at least in small steps, the permeability of social boundaries has begun to be relaxed, even though it is only for select groups of foreigners. Additionally, every foreigner has an obligation to complete an integration and adaptation course during the first year after their arrival in Czechia.

Another significant type of institutional inequality is related to the division in voting rights of immigrants who are living in Czechia. In accordance with the Election Acts (No. 491/2001 Coll., No. 62/2003 Coll.), EU citizens with a permanent residence permit have the right to vote in municipal elections as well as the European Parliament elections. On the other hand, citizens of third countries do not have any voting rights, except holders of Czech citizenship. It means not all immigrants who live long-term in Czechia have an equal possibility of influencing their living conditions in the receiving country. The government enables foreigners to come, work, and live in the country while limiting opportunities and withholding the right to change and enhance them until citizenship is obtained.

Even though Czechia does not have a self-standing integration law, its integration strategy has recently been intensively developing. The Ministry of the Interior drafted the first version of an immigrant integration policy in 2000 when the Alien Act came in force. Focusing on equal opportunities and non-discrimination, immigrant integration policy struggles towards 
similar rights for long-term residents as those received by Czech citizens. In 2006, 2011, and 2016, there were fundamental updates in the integration policy which paid attention primarily to social interaction between the majority population and immigrants by supporting good relations in everyday life negotiation. Since 2010, the Czech government has annually published an action plan which contains priorities, goals and means, and reports on the fulfilment of the action plan in the previous year.

\section{Conclusion}

This article has investigated the symbolic and social boundaries that hinder the integration process of Russian immigrants in Czechia. This study contributes to the literature on boundary-making, and particularly the case of Russian immigrants, in Czechia. The findings of this study are summarised henceforth. The significant factors that create boundaries discussed were (1) the development of Czech-Russian relationships, (2) the depiction of Russians in Czech media discourse, (3) the socio-economic status of Russian immigrants, and (4) the implementation of immigration and integration policies.

The positive attitudes towards the presence of Russians in Czechia as well as Czech-Russian collaboration were disturbed by the negative experiences during the communist regime. In particular, the invasion and military occupation of Czechoslovakia by the Soviet Army in 1968 left a dramatic footprint in the souls of the Czech people. Unfortunately, this collective trauma persists in the minds of elderly Czechs to the present day. As Klvaňová (2018) indicated, contemporary Russia's geopolitical behaviour saturates the negative majority attitudes due to a fear of history repeating itself. Collective trauma turns to collective guilt, for which current Russian immigrants are deemed responsible in Czechia. Memories of the negative historical events, as well as the majority perception of the current status, can influence the media depiction of Russians.

According to the media discourse analysis, 'Russian immigrants' are not a popular topic in the Czech press. However, the frequency is not so important in contrast to the narrative context, which created an overall impression on readers. In this regard, based on the most common narratives in the media, we can compile a typical image of a Russian immigrant in Czechia. Probably he will be an entrepreneur who operates in the real estate market and owns a large number of luxury apartments or castles, he is maybe involved in crime, or even he is a Russian spy; he gets along with the majority without any problems, even though he is sometimes able to provoke them, for example on the anniversary of the occupation of Czechoslovakia. A further result indicated that Russians rarely receive space in the Czech media to express their opinions, it means they belong to a powerless salient social group (van Dijk 1988) or in general to the 'others' (Spivak 1999; Estrada et al. 2016). And finally, the media use Russians as a general term, pertaining not only to foreigners from Russia but also other Russian-speaking immigrants; such a generalisation can lead to the distortion of reality.

In summary, negative experiences from the past feed the present majority perception through media representations, which help identify and determine in-group and out-group members. These practices contribute to the 'otherness' (Spivak 1999; Estrada et al. 2016) of Russians and enable the classification of people in society as 'us' and 'them' and draw symbolic boundaries (Lamont, Molnár 2002). Linking with a crime as well as a constant return to the past and a reminder of the events of 1968 classify Russians in Czech media as a threat. Thus, the power of media discourse has a significant impact on the creation and strengthening of symbolic boundaries in majority attitudes towards Russians that might lead to the reinforcement of negative attitudes (Sohoni, Sohoni 2014; Caviedes 2015; Estrada et al. 2016), limit their encounters, and therefore, obstruct their fruitful integration.

The higher education of Russians provides them the opportunity to get high-paying employment, and therefore, a better position on the social ladder. This combination of high education level and high economic activity ranks Russians as an elite immigrant group that differentiates them from others and the Czech majority as well, leading to the consolidation of social inequalities. It is a next example of the 'otherness' (Spivak 1999; Estrada et al. 2016), but in this case to which Russians contribute themselves. Thus, they are able to create social boundaries by their specificity.

However, Russians, as third-country immigrants, have an unequal legal status in comparison to foreigners from EU countries. The results of the research further show that the restrictive implementation of Czech immigration policy towards Russians, as well as other third-country immigrants, regulates their entrance, limits their access to the labour market, and defines them as 'they' or 'others'. As with the findings of previous studies (e.g. Heizmann, Böhnke 2018), a detailed investigation of Czech immigration policies confirms that there is an emphasis on legally privileged EU immigrants in comparison with immigrants from third countries who are legally disadvantaged. In sum, on the one hand, Russian immigrants create social boundaries themselves through their specific self-sufficient status that defines their social opportunities in society (Lamont, Molnár 2002). On the other hand, other sources of inequalities that lead to the creation of social boundaries are the implementation of immigration policies that are broadly accepted in society (Lamont, Molnár 2002).

Based on this study I suggest some concluding remarks that would help to make the process of 
integration easier for foreigners and fruitful for society in whole. First, members of the Czech majority society should intensify social contact with foreigners living in Czechia and behave towards newcomers with understanding and tolerance, regardless of their country of origin. Current immigrants cannot be responsible for past mistakes made by their predecessors. Moreover, in everyday negotiations and attitudes towards foreigners, it is incorrect to connect immigrants with political affairs taking place in their origin countries as they have left their motherland and live abroad. Second, the media should pay attention to how they represent immigrants who live among us and how that may impact their lives. At the same time, foreigners should be offered more avenues in which to express their opinions, and interest in them should be shown. In the process of building attitudes towards foreigners, readers should rely on their own experiences, not a mediated perception of news served by the media. Third, although it is difficult to imagine quick changes in legislation, Czech immigration and integration policies might adapt to all foreigners staying on its territory and intending to remain here.

\section{Acknowledgements}

This research was supported by Grant Agency of Charles University (grant project 'Multilevel separation of Russian immigrants in the post-socialist city', reg. № 192418) and Charles University Research Centre program UNCE/HUM/018. I would like to thank the two anonymous reviewers whose comments/suggestions helped improve this paper.

\section{References}

Act No. 326/1999 Coll., on the Residence of Foreign Nationals in the Czech Republic.

Act No. 491/2001 Coll., on Elections to Municipal Councils and on Amendments to Some Acts.

Act No. 62/2003 Coll., on Elections to the European Parliament and on Amendments to Some Acts.

Allport, G. W. (1954): The Nature of Prejudice. Reading, MA: Addison-Wesley.

Bail, C. A. (2008): The Configuration of Symbolic Boundaries against Immigrants in Europe. American Sociological Review 73, 37-59, https://doi.org /10.1177/000312240807300103.

Baršová, A., Barša, P. (2005): Přistěhovalectví a liberální stát. Imigrační a integrační politiky v USA, západní Evropě a Česku. Masarykova univerzita, Mezinárodní politologický ústav, Brno, 205-255.

Barvíková, H. (2005): Ruští emigranti v Československu v letech 1918-1938. In: Exil v Praze a Československu 1918-1938. Pražská edice, Praha, 9-21.

Bleich, E., Bloemraad, I., de Graauw, E. (2015): Migrants, Minorities and the Media: Information, Representation, and Participation in the Public Sphere. Journal of Ethnic and Migration Studies 41, 857-873, https://doi.org /10.1080/1369183X.2014.1002197.

Bosswick, W., Heckmann, F. (2006): Integration of migrants: Contribution of local and regional authorities. European Foundation for the Improvement of Living and Working Conditions, Dublin.

Caviedes, A. (2015): An Emerging 'European' News Portrayal of Immigration? Journal of Ethnic and Migration Studies 41, 897-917, https://doi.org/10.1080 /1369183X.2014.1002199.

Czech Statistical Office (2019): Foreigners in the Czech Republic. Prague.

Drbohlav, D., Janská, E. (2004): Current Ukrainian and Russian Migration to the Czech Republic: Mutual Similarities and Differences. In: Górny, A., Ruspini, P. (eds.): Migration in the New Europe, East-West Revisited. Palgrave Macmillan, London, 49-64.

Drbohlav, D., Lachmanová-Medová, L., Čermák, Z., Janská, E., Čermáková, D., Dzúrová, D. (2009): The Czech Republic: on its way from emigration to immigration country. IDEA Working Papers.

Drbohlav, D. et al. (2010): Migrace a (i)migranti v Česku. Kdo jsme, odkud přicházíme, kam jdeme? Praha, SLON.

European Comission (2017): Special Eurobarometer 469 Integration of Immigrants in the European Union. https://ec.europa.eu/commfrontoffice/publicopinion /index.cfm/survey/getsurveydetail/instruments /special/surveyky/2169.

Heizmann, B. (2016): Symbolic boundaries, incorporation policies, and anti-immigrant attitudes: what drives exclusionary policy preferences? Ethnic and Racial Studies 39(10), 1791-1811, http://dx.doi.org/10.1080 /01419870.2015.1124128.

Heizmann, B., Böhnke, P. (2018): Immigrant life satisfaction in Europe: the role of social and symbolic boundaries. Journal of Ethnic and Migration Studies 45(7), 1027-1050, https://doi.org/10.1080/1369183X .2018.1438252.

Janíčko, M. (2010): Pražští Rusové (The Prague Russians). Bachelor's thesis. Charles University in Prague, Department of Sociology.

Klvaňová, R. (2018): 'The Russians are back': Symbolic boundaries and cultural trauma in immigration from the former Soviet Union to the Czech Republic. Ethnicities 0(0), 1-20. https://doi.org/10.1177 /1468796817752740.

Kopřivová, A. (2001): Střediska ruského emigrantského života v Praze (1921-1952). Praha: Národní knihovna ČR, Slovanská knihovna.

Kratochvíl, P., Cibulková, P., Beneš, V. (2006): Foreign policy, rhetorical action and the idea of otherness: The Czech Republic and Russia. Communist and Post-Communist Studies 39(4), 497-511, https://doi.org/10.1016 /j.postcomstud.2006.09.002.

Kušniráková, T., Čižinský, P. (2011): Dvacet let české migrační politiky: Liberální, restriktivní, anebo ještě jiná? Geografie 116(4), 497-517, https://doi.org /10.37040/geografie2011116040497.

Lamont, M., Molnár, V. (2002): The Study of Boundaries in the Social Sciences. The Annual Review of Sociology 28, 167-195, https://doi.org/10.1146/annurev.soc.28 .110601.141107.

Lawlor, A. (2015): Local and National Accounts of Immigration Framing in a Cross-national Perspective. 
Journal of Ethnic and Migration Studies 41, 918-941, https://doi.org/10.1080/1369183X.2014.1001625.

Neumann, R., Moy, P. (2018): You're (Not) Welcome: The Impact of Symbolic Boundaries, Intergroup Contact, and Experiences with Discrimination on Immigration Attitudes. American Behavioral Scientist 62(4), 458-477, https://doi.org/10.1177/0002764218760370.

Pettigrew, T. F. (1998): Intergroup contact theory. Annual Review of Psychology, 49(1), 65-85, https://doi.org /10.1146/annurev.psych.49.1.65.

Sládek, Z. (1999): České prostředí a ruská emigrace (1918-1938). In: Běloševská, L.: Duchovní proudy ruské a ukrajinské emigrace v Československé republice (1919-1939). Slovanský ústav AV ČR, Praha, 7-46.

Sládek, K. (2010): Ruská diaspora v České republice: Sociální, politická a religiózní variabilita ruské migrace, Pavel Mervart, Červený Kostelec.

Sohoni, D., Sohoni, T. W. P. (2014): Perceptions of Immigrant Criminality: Crime and Social Boundaries.
The Sociological Quarterly 55(1), 49-71, https:// doi.org/10.1111/tsq.12039.

Spivak, G. S. (1999): A Critique of Postcolonial Reason: Toward a History of the Vanishing Present. Cambridge: Harvard University Press.

Sýkora, L., Bouzarovski, S. (2012): Multiple transformations: Conceptualising the post-communist urban transition. Urban Studies 49(1), 43-60.

van Dijk, T. A. (1988): News analysis. Case studies of international and national news in the press. Lawrence Erlbaum Associates, Publishers, Hillsdale, New Jersey. Vavrečková, J., Dobiášová, K. (2015): Začlenění ruské komunity do většinové společnosti (Incorporation of Russian community into majority society). Výzkumný ústav práce a sociálních věcí, v.vi.i, Univerzita Karlova v Praze, Fakulta sociálních věd.

Večerník, J. (2002): Výzkum společenské transformace a česká sociologie (Transition Studies and Czech sociology). Sociologický časopis 38(1-2), 55-77. 